\title{
Association between PD-L1 expression combined with tumor- infiltrating lymphocytes and the prognosis of patients with advanced hypopharyngeal squamous cell carcinoma
}

\author{
Takeharu Ono ${ }^{1}$, Koichi Azuma ${ }^{2}$, Akihiko Kawahara ${ }^{3}$, Tetsuro Sasada ${ }^{4}$ Satoshi \\ Hattori' ${ }^{5}$, Fumihiko Sato ${ }^{1}$, Buichiro Shin ${ }^{1}$, Shun-Ich Chitose ${ }^{1}$, Jun Akiba ${ }^{3}$ and Umeno \\ Hirohito $^{1}$ \\ ${ }^{1}$ Department of Otolaryngology-Head and Neck Surgery, Kurume University School of Medicine, Kurume, Japan \\ ${ }^{2}$ Division of Respirology, Neurology, and Rheumatology, Department of Internal Medicine, Kurume University School of \\ Medicine, Kurume, Japan \\ ${ }^{3}$ Department of Diagnostic Pathology, Kurume University Hospital, Kurume, Japan \\ ${ }^{4}$ Cancer Vaccine Center, Kanagawa Cancer Center Research Institute, Yokohama, Japan \\ ${ }^{5}$ Biostatistics Center, Kurume University School of Medicine, Kurume, Japan \\ Correspondence to: Takeharu Ono, email: ono123@med.kurume-u.ac.jp \\ Keywords: PD-L1, immunohistochemistry, hypopharyngeal squamous cell carcinoma, neoadjuvant chemotherapy, CD8+ TILS \\ Received: March 24, $2017 \quad$ Accepted: September 05, $2017 \quad$ Published: October 06, 2017 \\ Copyright: Ono et al. This is an open-access article distributed under the terms of the Creative Commons Attribution License 3.0 \\ (CC BY 3.0), which permits unrestricted use, distribution, and reproduction in any medium, provided the original author and source \\ are credited.
}

\section{ABSTRACT}

Limited information is available regarding the immune-related prognostic factors of patients with advanced hypopharyngeal squamous cell carcinoma (HPSCC). The expression of programmed cell death-ligand 1 (PD-L1) in tumor cells contributes to a mechanism that allows cancer cells to escape immune surveillance. We investigated whether PD-L1 or human leukocyte antigen (HLA) class I expression in tumor cells and the tumor-infiltrating lymphocyte (TIL) density were associated with the tumor response to neoadjuvant chemotherapy (NAC) and survival in patients with advanced HPSCC. We retrospectively reviewed 83 consecutive patients with stage III or IV HPSCC who received NAC. We evaluated PD-L1 and HLA class I expression and TIL density using immunohistochemistry. Univariate and multivariate analyses demonstrated that $\mathrm{CDB}^{+}$TIL density was an independent and significant predictive factor for the response to NAC, progression-free survival (PFS) and overall survival (OS), whereas PD-L1 or HLA class I expression did not significantly correlate. The subgroup analysis revealed that a higher $\mathrm{CDB}^{+}$TIL density without detectable PDL1 expression tended to be associated with longer patient survival. These results suggest that PD-L1 expression levels combined with CD8 ${ }^{+}$TIL density may serve as a predictive biomarker for patients with stage III or IV HPSCC receiving NAC.

\section{INTRODUCTION}

Hypopharyngeal squamous cell carcinoma (HPSCC) accounts for 3\%-5\% of all head and neck squamous cell carcinoma (HNSCC) [1]. Most patients with HPSCC present with advanced disease and have the worst prognosis among those with HNSCCs arising from different anatomical sites, despite the development of treatments comprised of surgery and chemotherapy with or without radiotherapy [2].

Although neoadjuvant chemotherapy (NAC) has no clear evidence of survival benefits [3], it has been used as a treatment option for larynx-preservation in locally advanced laryngeal and hypopharyngeal cancer $[4,5]$. Despite the correlation between tumor responses to NAC and patient prognosis $[6,7]$, few reports describing the 
predictive biomarkers for tumor responses to NAC are available in the context of HNSCC $[8,9]$.

The CD28 protein family member, programmed cell death 1 (PD-1), is a receptor expressed on the surface of T cells, which suppresses their activation and proliferation. The binding of PD-1 to its ligand, programmed cell deathligand 1, induces apoptosis or exhaustion in activated $\mathrm{T}$ cells, and inhibition of this interaction enhances the antitumor activity of T cells [10]. Therefore, PD1 and PD-L1 are considered immune checkpoint molecules. PD-L1 is frequently overexpressed in many types of human cancers [10], and therefore, the PD-1/PD-L1 axis is considered to contribute to a mechanism that allows cancers to escape immune surveillance. Specific antibodies, which act as immune checkpoint blockers to inhibit the interactions between PD-1 and its ligands, PDL1 and PD-L2, exhibit promising clinical efficacy against certain malignancies [11-13].

Currently, there is limited information available regarding the prognostic values of PD-L1 or HLA class I expression and TILs in patients with HPSCC receiving NAC. Therefore, this study aimed to evaluate the predictive relevance of these factors in patients with advanced HPSCC who received NAC.

\section{RESULTS}

\section{Patient characteristics}

The clinical characteristics of the 83 patients included in this study are presented in Table 1. The median age of the patients at diagnosis was 65 years (range: $40-80$ years). A total of 79 patients (95\%) were men, and $75(90 \%), 6(7 \%)$, and $2(2 \%)$ patients had PS (0), PS (1), and PS (2), respectively. Mild ( $<40$ packs of cigarettes per year) and heavy ( $\geq 40$ packs of cigarettes per year) smokers consisted of $33(40 \%)$ and 45 (54\%) patients, respectively. Moderate (10-30 g/day) and heavy ( $\geq 30 \mathrm{~g} /$ day) alcohol consumers consisted of 38 (46\%) and $40(48 \%)$ patients, respectively. Tumor histology was classified as well differentiated (30 patients), moderately differentiated (42 patients), or poorly differentiated (11 patients). The anatomical subsites were classified as pyriform sinus (70 patients), post-cricoid (6 patients), and posterior wall ( 7 patients). In accordance with the system adopted by the Union for International Cancer Control (UICC) TNM Classification of Malignant Tumors $7^{\text {th }}$ edition [14], $16(19 \%), 55(66 \%)$, and $12(15 \%)$ patients, respectively exhibited stage III, IVA, or IVB disease at the time of diagnosis.

\section{Treatment protocol}

The various treatments and associated tumor responses are shown in Table 1. All patients received platinum and fluorouracil-based agents as NAC as for the initial treatment. A total of 45 patients received intravenous PF $\left(20 \mathrm{mg} / \mathrm{m}^{2}\right.$ cisplatin on days $1-5$ and 1000 $\mathrm{mg} / \mathrm{m}^{2} 5$-fluorouracil on days $1-5$ in one cycle) and 38 patients received TPF $\left(60 \mathrm{mg} / \mathrm{m}^{2}\right.$ docetaxel on day 1,60 $\mathrm{mg} / \mathrm{m}^{2}$ cisplatin on day 1 , and $700 \mathrm{mg} / \mathrm{m}^{2}$ 5-fluorouracil on days 1-4 in one cycle). An evaluation of the tumor response to NAC based on the response evaluation criteria in solid tumors, was performed using computed tomography and magnetic resonance imaging. Partial responses (PR), stable disease (SD), and progressive disease (PD) were observed in $39(47 \%), 34(41 \%)$, and $10(12 \%)$ patients, respectively. Six patients $(7 \%)$ received palliative treatment because of rapid locoregional progression or the appearance of distant metastasis, 29 patients $(35 \%)$ received concurrent chemoradiotherapy (CCRT) containing platinum and 5-fluorouracil-based agents, and 48 patients (58\%) received surgical treatment (e.g., transoral resection or total pharyngolaryngectomy) combined with a neck dissection. Twenty (24\%) and eight (10\%) patients received RT and CCRT, respectively, as a post-operative treatment. Post-operative RT for primary and regional sites consisting of a single daily irradiation administered at 1.8 Gy per fraction (total: 60-61Gy), was initiated 3-4 weeks after surgery. Definitive or postoperative CCRT containing cisplatin $\left(5 \mathrm{mg} / \mathrm{m}^{2}\right.$ on days $1-15)$ and 5 -fluorouracil $\left(250 \mathrm{mg} / \mathrm{m}^{2}\right.$ on days 115$)$ was performed with a daily irradiation administered at $1.8 \mathrm{~Gy}$ per fraction (total: 61-71Gy).

\section{PD-L1 or HLA class I expression and $\mathrm{CD3}^{+}$, $\mathrm{CD4}^{+}$, or $\mathrm{CD8}^{+}$TIL density}

We restricted our immunohistochemical analysis to PD-L1 or HLA class I expression and $\mathrm{CD}^{+}, \mathrm{CD}^{+}$, or $\mathrm{CD}^{+} \mathrm{TIL}$ density due to limited tissue availability. Figure 1 shows the representative staining patterns of PD-L1, HLA class I, CD3, CD4, and CD8 in the tumor specimens. PD-L1 expression was observed in the membrane, cytoplasm, or both in tumor cells and/or stromal lymphocytes. PD-L1 expression in the tumors [tumor proportion score (TPS) $\geq 1 \%$ ] was detected in $26(31 \%)$ patients. Regarding the expression of HLA class I in tumor cells, positive (expression level $\geq 75 \%$ ), heterogeneous (expression level: 25\%-74 \%), and negative (expression level $<25 \%)$ staining was detected in 14 (17\%), 34 (41\%), and $35(42 \%)$ of patients, respectively (Table 1). The median number of $\mathrm{CD}^{+}, \mathrm{CD}^{+}$, and $\mathrm{CD}^{+}$TILs were 50 (range: 0-383), 21 (range: 0-186), and 36 (range: 0-347), respectively; these values were used to discriminate patients with high or low TIL density. Although we examined the expression of P16, which was associated with HPV infection, using immunohistochemistry, the $\mathrm{CD}^{+}$TIL density was not correlated with the level of P16 expression (data not shown). 
Table 1: Patients' characteristics

\section{Characteristics}

Age (years) $(n=83)$

Performance status

Sex

Follow up (month)

Progression-free survival (month)

Median

Range

Overall survival (month)

Median

Range

Current status

Dead

Alive

Smoking status

Never
Mild
Heavy

Alcohol status

$$
\text { Never }
$$$$
\text { Moderate }
$$

Heavy

Differentiation
24

N (\%)

65

$40-80$

$75(90)$

$6(7)$

$2(2)$

$79(95)$

$4(5)$

32

$2-127$

$1-127$

32

$2-127$

$48(58)$

$35(42)$

$33(40)$

$45(54)$

$5(6)$

$38(46)$

$40(48)$

30 (36)

$42(51)$

$11(13)$

(Continued) 


\section{Characteristics}

N (\%)

Subsite

$\begin{array}{cc}\text { Pyriform sinus } & 70(84) \\ \text { Post cricoid } & 6(7) \\ \text { Posterior wall } & 7(8)\end{array}$

T stage

$\begin{array}{lc}\mathrm{T} 1 & 0 \\ \mathrm{~T} 2 & 15(18) \\ \mathrm{T} 3 & 38(46) \\ \mathrm{T} 4 & 30(36)\end{array}$

N Stage

$\begin{array}{ll}\text { N0 } & 10(12) \\ \text { N1 } & 13(16) \\ \text { N2 } & 49(59) \\ \text { N3 } & 11(13)\end{array}$

Stage

III $16(19)$

IVA $\quad 55(66)$

IVB $12(15)$

NAC categories

$\begin{array}{cc}\text { PF } & 45(54) \\ \text { TPF } & 38(46)\end{array}$

Response to NAC

$\begin{array}{cc}\text { Complete response } & 0 \\ \text { Partial response } & 39(47) \\ \text { Stable disease } & 34(41) \\ \text { Progressive disease } & 10(12)\end{array}$

Definitive treatment

$\begin{array}{cc}\text { Surgery } & 48(58) \\ \text { CCRT } & 29(35) \\ \text { Palliation } & 6(7)\end{array}$

Postoperative treatment

$\begin{array}{cc}\text { None } & 20(24) \\ \text { RT } & 20(24) \\ \text { CCRT } & 8(10)\end{array}$

(Continued) 


\begin{tabular}{lcc}
\hline Characteristics & & N (\%) \\
\hline HLA class I expression & $<25 \%$ & $35(42)$ \\
& $25-74$ & $34(41)$ \\
& $\geq 75 \%$ & $14(17)$ \\
PD-L1 TPS & $<1 \%$ & $57(68)$ \\
& $1 \%-49 \%$ & $13(16)$ \\
& $\geq 50 \%$ & $13(16)$ \\
\hline
\end{tabular}

NAC, neoadjuvant chemotherapy; PF, cisplatin and 5-fluorouracil; TPF, docetaxel, cisplatin, and 5-fluorouracil; TPS, tumor proportion score; CCRT, concurrent chemoradiotherapy.

\section{Correlation between PD-L1 or HLA class I expression and patient characteristics}

The relationships between PD-L1 or HLA class I expression and patient demographics are presented in Table 2. No significant correlations were not detected between PD-L1 expression and age $(\mathrm{p}=0.479)$, smoking status $(\mathrm{p}=1.000)$, alcohol consumption $(\mathrm{p}=0.488)$, performance status $(\mathrm{p}=0.710)$, tumor differentiation ( $p$ $=0.139)$, T classification $(\mathrm{p}=1.000)$, or $\mathrm{N}$ classification $(p=0.605)$. The correlation between PD-L1 and HLA class I expression was significant $(\mathrm{p}=0.030)$; however,
PD-L1 expression was not significantly associated with the $\mathrm{CD}^{+}$TIL density $(\mathrm{p}=1.000)$. In addition, PD-L1 expression tended to be positively correlated with $\mathrm{CD}^{+}$ $(\mathrm{p}=0.061)$ and $\mathrm{CD}^{+}(\mathrm{p}=0.061)$ TIL density, albeit this was not statistically significant. Of note, significant correlations were found between PD-L1 expression and $\mathrm{CD}^{+}(\mathrm{p}=0.010)$ or $\mathrm{CD}^{+}(\mathrm{p}=0.022)$ TIL density when these TIL densities were analyzed as continuous variables (Supplementary Figure 1).

Regarding the correlation with HLA class I expression, significant differences were not detected for age $(\mathrm{p}=0.570)$, smoking status $(\mathrm{p}=0.151)$, alcohol
A
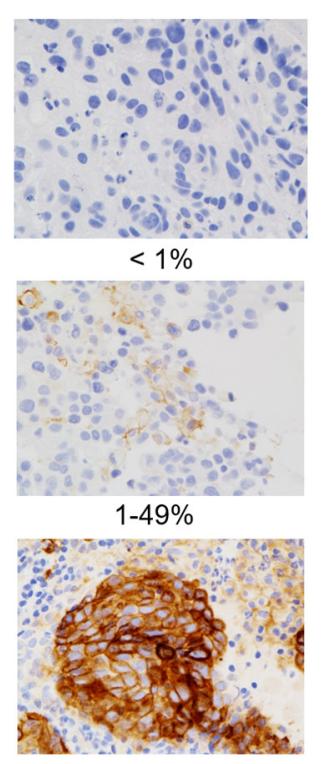

$\geq 50 \%$
B

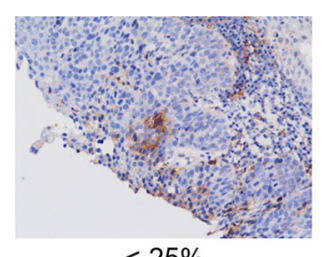

$<25 \%$

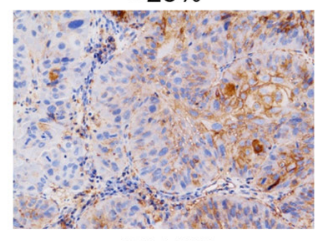

$25-74 \%$

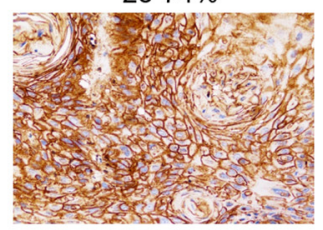

$\geq 75 \%$
C

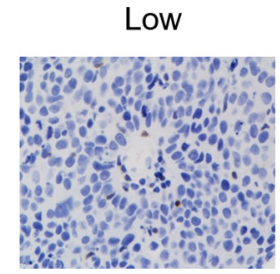

CD4

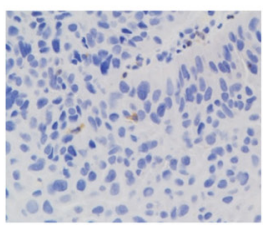

CD8

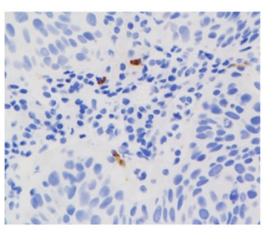

High
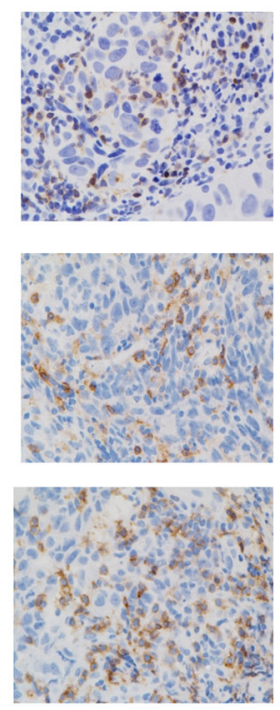

Figure 1: Immunohistochemical (IHC) staining patterns of PD-L1, HLA class I, CD3, CD4, and CD8 of patients with advanced hypopharyngeal squamous cell carcinoma. Representative examples of patients whose tumor proportion scores (TPS) were classified as $<1 \%, 1 \%-49 \%$, and $\geq 50 \%$ for the membrane expression of PD-L1 are shown (A). The level of HLA class I expression was classified as $<25 \%, 25 \%-74 \%$, and $\geq 75 \%$ (B). High or low IHC staining patterns for CD3 $3^{+}$, CD4 $4^{+}$, and CD $8^{+}$TILs are shown (C). 
Table 2: Relationship between PD-L1 or HLA class I expression and patients' characteristics

\begin{tabular}{|c|c|c|c|c|c|c|c|}
\hline \multirow{2}{*}{ Characteristic } & \multirow{2}{*}{$\mathbf{N}$} & \multicolumn{3}{|c|}{ PD-L1 } & \multicolumn{3}{|c|}{ HLA class I } \\
\hline & & Negative & Positive & $P$ value $^{\mathrm{a}}$ & Low & High & $P$ value $^{\text {a }}$ \\
\hline & 83 & 57 & 26 & & 69 & 14 & \\
\hline \multicolumn{8}{|l|}{ Age (years) } \\
\hline$\leq 65$ & 42 & 27 & 15 & 0.479 & 36 & 6 & 0.570 \\
\hline$>65$ & 41 & 30 & 11 & & 33 & 8 & \\
\hline \multicolumn{8}{|l|}{ Smoking status } \\
\hline Never or Mild & 38 & 26 & 12 & 1.000 & 29 & 9 & 0.151 \\
\hline Heavy & 45 & 31 & 14 & & 40 & 5 & \\
\hline \multicolumn{8}{|l|}{ Alcohol status } \\
\hline $\begin{array}{l}\text { Never or } \\
\text { Moderate }\end{array}$ & 43 & 28 & 15 & 0.488 & 35 & 8 & 0.773 \\
\hline Heavy & 40 & 29 & 11 & & 34 & 6 & \\
\hline \multicolumn{8}{|l|}{$\begin{array}{l}\text { Performance } \\
\text { status }\end{array}$} \\
\hline 0 & 75 & 52 & 23 & 0.710 & 63 & 12 & 0.617 \\
\hline 1 or 2 & 8 & 5 & 3 & & 6 & 2 & \\
\hline \multicolumn{8}{|l|}{ Differentiation } \\
\hline Well & 30 & 24 & 6 & 0.139 & 25 & 5 & 1.000 \\
\hline $\begin{array}{l}\text { Moderately or } \\
\text { Poorly }\end{array}$ & 53 & 33 & 20 & & 44 & 9 & \\
\hline \multicolumn{8}{|l|}{$\mathrm{T}$ classification } \\
\hline $\mathrm{T} 2$ & 15 & 10 & 5 & 1.000 & 12 & 3 & 0.711 \\
\hline T3-4 & 68 & 47 & 21 & & 57 & 11 & \\
\hline \multicolumn{8}{|l|}{$\mathrm{N}$ classification } \\
\hline N0-1 & 23 & 17 & 6 & 0.605 & 18 & 5 & 0.518 \\
\hline $\mathrm{N} 2-3$ & 60 & 40 & 20 & & 51 & 9 & \\
\hline \multicolumn{8}{|l|}{ HLA class I } \\
\hline High & 14 & 6 & 8 & 0.030 & - & - & - \\
\hline Low & 69 & 51 & 18 & & - & - & \\
\hline \multicolumn{8}{|l|}{ CD3 } \\
\hline High & 41 & 28 & 13 & 1.000 & 30 & 11 & 0.020 \\
\hline Low & 42 & 29 & 13 & & 39 & 3 & \\
\hline \multicolumn{8}{|l|}{$\mathrm{CD} 4$} \\
\hline High & 41 & 24 & 17 & 0.061 & 32 & 9 & 0.245 \\
\hline Low & 42 & 33 & 9 & & 37 & 5 & \\
\hline \multicolumn{8}{|l|}{ CD8 } \\
\hline High & 41 & 24 & 17 & 0.061 & 30 & 11 & 0.020 \\
\hline Low & 42 & 33 & 9 & & 39 & 3 & \\
\hline
\end{tabular}

aFisher's exact test. 
consumption $(p=0.773)$, performance status $(p=0.617)$, tumor differentiation $(\mathrm{p}=1.000)$, $\mathrm{T}$ classification $(\mathrm{p}=$ $0.711), \mathrm{N}$ classification $(\mathrm{p}=0.518)$, or $\mathrm{CD} 4^{+}$TIL density $(\mathrm{p}=0.245)$. In contrast, $\mathrm{CD} 3^{+}$or $\mathrm{CD} 8^{+} \mathrm{TIL}$ density was significantly correlated with HLA class I expression ( $\mathrm{p}=$ 0.020 and $p=0.020$, respectively).

\section{Correlation between the tumor response to NAC and patient characteristics}

Patients who exhibited a partial response (PR) to NAC were defined as responders, whereas those with stable disease (SD) or progressive disease (PD) were defined as non-responders. As shown in Supplementary Figure 2, the responders to NAC were associated with a significantly better prognosis than the non-responders.
The relationships between the response rate (RR) to NAC and patient demographics are presented in Table 3 . In the univariate analysis, N classification (RR: N0-N1vs. N23, 65.2\% vs. $40 \%$; $=0.043$ ), $\mathrm{CD}^{+}$TIL density (RR: high vs. low, $58.5 \%$ vs. $35.7 \%$; $=0.039)$, and $\mathrm{CD}^{+} \mathrm{TIL}$ density (RR: high vs. low, $63.4 \%$ vs. $31.0 \%$; p = 0.004) were significantly correlated with the tumor response to NAC. HLA class I expression was not included in the multivariate analysis because it was significantly correlated with PD-L1 expression, $\mathrm{CD}^{+}$TIL density, or $\mathrm{CD}^{+}$TIL density $(\mathrm{p}=0.030,0.020$, and 0.020 , respectively). The multivariate analysis demonstrated that $\mathrm{N}$ classification (odds ratio [OR]: 0.29; 95\% confidence interval [CI]: 0.09-0.89; $\mathrm{p}=0.031)$ and $\mathrm{CD} 8^{+}$TILs density (OR: 0.32 ; 95\%CI: $0.11-0.95 ; \mathrm{p}=0.039$ ) were significant factors for the tumor response to NAC.

Table 3: Univariate and multivariate analyses of clinicopathologic factors associated with response to NAC

\begin{tabular}{|c|c|c|c|c|}
\hline \multirow{3}{*}{ Factor } & \multirow{3}{*}{$\mathbf{N}$} & Response rate (\%) & Univariate & Multivariate \\
\hline & & & $P$ value ${ }^{\mathrm{a}}$ & $P$ value ${ }^{\mathrm{a}}$ \\
\hline & & & OR $(95 \%$ CI $)$ & OR $(95 \% \mathrm{CI})$ \\
\hline
\end{tabular}

Age (years)

$\leq 65$

$>65$

42

41

56.1

38.1

0.102

0.154

Smoking status

Never or Mild

38

45

39.5

0.209

Heavy

53.3

$1.75(0.73-4.20)$

Alcohol status

Never or Moderate

43

Heavy

40

48.8

45.0

0.726

Performance status

0

1 or 2

75

8

48.0

37.5

50.0

Well

Moderately or

poorly

45.3

$\mathrm{T}$ classification

T2

T3-4

15

68

$\mathrm{N}$ classification

N0-1

23

N2-3

60

46.7

47.1

65.2

40.0
$0.86(0.36-2.03)$

$$
0.574
$$

$0.65(0.15-2.92)$
0.679
$1.21(0.49-2.96)$

\subsection{8}

0.628

$1.02(0.33-3.11)$

$0.73(0.20-2.60)$

0.043

0.031

$0.36(0.13-0.98)$

$0.29(0.09-0.89)$

(Continued) 


\begin{tabular}{|c|c|c|c|c|}
\hline \multirow{3}{*}{ Factor } & \multirow{3}{*}{$\mathbf{N}$} & \multirow[t]{3}{*}{ Response rate $(\%)$} & Univariate & \multirow{3}{*}{$\begin{array}{c}\text { Multivariate } \\
P \text { value }^{\mathrm{a}} \\
\text { OR }(95 \% \mathrm{CI})\end{array}$} \\
\hline & & & $P$ value ${ }^{a}$ & \\
\hline & & & OR (95\% CI) & \\
\hline \multicolumn{5}{|c|}{ NAC categories } \\
\hline $\mathrm{PF}$ & 45 & 48.9 & 0.706 & \\
\hline TPF & 38 & 44.7 & $0.84(0.36-2.01)$ & \\
\hline \multicolumn{5}{|l|}{ HLA class I } \\
\hline High & 14 & 57.1 & 0.407 & \\
\hline Low & 69 & 44.9 & $0.61(0.19-1.95)$ & \\
\hline \multicolumn{5}{|l|}{ PD-L1 } \\
\hline Positive & 26 & 53.8 & 0.399 & 0.591 \\
\hline Negative & 57 & 43.9 & $0.67(0.26-1.70)$ & $0.73(0.24-2.26)$ \\
\hline \multicolumn{5}{|l|}{$\mathrm{CD} 3$} \\
\hline High & 41 & 58.5 & 0.039 & 0.378 \\
\hline Low & 42 & 35.7 & $0.39(0.16-0.95)$ & $0.61(0.20-1.82)$ \\
\hline \multicolumn{5}{|l|}{ CD4 } \\
\hline High & 41 & 51.2 & 0.446 & 0.711 \\
\hline Low & 42 & 42.8 & $0.71(0.30-1.70)$ & $0.81(0.28-2.39)$ \\
\hline \multicolumn{5}{|l|}{ CD8 } \\
\hline High & 41 & 63.4 & 0.004 & 0.039 \\
\hline Low & 42 & 31.0 & $0.26(0.10-0.64)$ & $0.32(0.11-0.95)$ \\
\hline
\end{tabular}

${ }^{a}$ Logistic regression analysis; OR, odds ratio; CI, confidence interval; NAC, neoadjuvant chemotherapy; PF, cisplatin and 5-fluorouracil; TPF, docetaxel, cisplatin, and 5-fluorouracil.

\section{Survival analysis}

At the time of analysis, the median follow-up time for all patients was 32 months, and 35 patients $(42 \%)$ were alive at the time of the last follow-up (Table 1). The median progression-free survival (PFS) and overall survival (OS) were 24 and 32 months, respectively, and PFS and OS rates at 60 months were $41.9 \%$ and $42.5 \%$, respectively. A Kaplan-Meier analysis was performed to evaluate whether PD-L1 or HLA class I expression and $\mathrm{CD}^{+}, \mathrm{CD}^{+}$, or $\mathrm{CD} 8^{+} \mathrm{TIL}$ density were associated with PFS or OS (Figure 2). The expression of PD-L1 or HLA class I was not significantly correlated with PFS (positive vs negative: median 21.9 vs. 31.9 months, $p=0.316$; high vs. low: median not reached [NR] vs. 20.5 months; $p=$ 0.149 ; respectively] or OS (positive vs. negative: median 28.4 vs. 35.1 months, $\mathrm{p}=0.397$; high vs. low: median NR vs. 31.9 months, $p=0.233$; respectively). Although the differences were not significant, patients with higher numbers of $\mathrm{CD}^{+}$TILs tended to have a longer PFS (high vs. low: median NR vs. 10.4 months; $p=0.062)$, but not OS (high vs. low: median NR vs. 28.4 months; $\mathrm{p}=0.181$ ). $\mathrm{CD}^{+}$TIL density did not exhibit a significant correlation with PFS (high vs. low: median 23.5 vs. 24.1 months, $p=$ 0.382 ) or OS (high vs. low: median NR vs. 31.9 months, $p$ $=0.261)$. In contrast, patients with higher numbers of $\mathrm{CD} 8^{+}$ TILs experienced significantly longer PFS (high vs. low: median NR vs. 9.5 months; $p<0.001$ ) and OS (high vs. low: median NR vs. 18.6 months; $p=0.001$ ). Furthermore, the univariate analysis indicated that $\mathrm{N}$ classification was a significant predictive factor of OS (hazard ratio [HR]: 0.47; 95\%CI: 0.21-0.93; $p=0.029$ ) (Table 4).

The multivariate analyses revealed that the density of $\mathrm{CD}^{+}$TILs was an independent and significant predictive factor of PFS (HR: 0.33 ; 95\%CI: $0.16-0.62$; $\mathrm{p}=0.001)$ and OS (HR: 0.38 ; 95\%CI: 0.19-0.75; $\mathrm{p}=$ 0.005 ) (Table 4). In addition, the multivariate analysis revealed that $\mathrm{N}$ classification was a significant factor associated with OS (HR: 0.49 ; 95\%CI: $0.22-0.99 ; \mathrm{p}=$ 0.048 (Table 4). 


\section{Correlation between survival and PD-L1 expression combined with $\mathrm{CD8}^{+}$TIL density}

We performed subanalyses to determine whether the combination of PD-L1 expression and $\mathrm{CD} 8^{+} \mathrm{TIL}$ density could predict patient prognosis. For this purpose, patients were divided into four subgroups, which were defined by PD-L1 expression and CD $8^{+}$TIL density [15, 16]. A Kaplan-Meier analyses of PFS and OS in the four subgroups (PD-L1 $/ \mathrm{CD} 8^{\text {high }}, \mathrm{PD}^{2} 1^{+} / \mathrm{CD} 8^{\text {high }}$, $\mathrm{PD}-\mathrm{L} 1^{1} /$ $\mathrm{CD} 8^{\text {low }}$, and $\left.\mathrm{PDL1}^{+} / \mathrm{CD} 8^{\text {low }}\right)$ are presented in Figure 3 . The median PFS values were NR in the PD-L1/CD ${ }^{\text {high }}$ group, 25.6 months in the $\mathrm{PD}-\mathrm{L1}^{+} / \mathrm{CD} 8^{\text {high }}$ group, 10.8 months in the PD-L1\% $/ \mathrm{CD}^{\text {low }}$ group, and 7.9 months in the PD$\mathrm{L}^{+} / \mathrm{CD} 8^{\text {low }}$ group $(\mathrm{p}=0.006)$ (Figure $\left.3 \mathrm{~A}\right)$. The univariate analysis revealed that the PFS of the $\mathrm{CD} 8^{\text {high }}$ group was longer than that of the $\mathrm{CD} 8^{\text {low }}$ group in patients negative or positive for $\mathrm{PD}-\mathrm{L} 1$ expression $\left(\mathrm{PD}-\mathrm{L} 1^{+} / \mathrm{CD} 8^{\text {high }}\right.$ vs $\mathrm{PD}$ $\mathrm{L}^{+} / \mathrm{CD}^{\text {low }}, \mathrm{p}=0.044 ; \mathrm{PD}-\mathrm{L} 1 / \mathrm{CD} 8^{\text {high }}$ vs $\mathrm{PD}-\mathrm{L} 1 / \mathrm{CD} 8^{\text {low }}$ groups, $p=0.001$, respectively). In addition, although not statistically significant, the PFS of the PD-L1/CD $8^{\text {high }}$ group also tended to be longer than that of the $\mathrm{PD}-\mathrm{L1}^{+} /$ $\mathrm{CD} 8^{\text {high }}$ group $(\mathrm{p}=0.072)$.

The median OS was NR in the PD-L1 $/ \mathrm{CD} 8^{\text {high }}$ group, 34.0 months in the $\mathrm{PD}-\mathrm{L1}^{+} / \mathrm{CD} 8^{\text {high }}$ group, 25.1 months in the $\mathrm{PD}-\mathrm{L} 1 / \mathrm{CD} 8^{\text {low }}$ group, and 14.3 months in the $\mathrm{PD}-\mathrm{L}^{+} / \mathrm{CD}^{\text {low }}$ group $(\mathrm{p}=0.011)$ (Figure $\left.3 \mathrm{~B}\right)$. The univariate analysis revealed that the $\mathrm{OS}$ of the $\mathrm{CD} 8^{\text {high }}$ group was longer than that of the $\mathrm{CD} 8^{\text {low }}$ group in patients with negative or positive PD-L1 expression $\left(\mathrm{PD}-\mathrm{L}^{+} /\right.$ $\mathrm{CD} 8^{\text {high }}$ vs. PD-L1 ${ }^{+} / \mathrm{CD} 8^{\text {low }}, \mathrm{p}=0.132$ and $\mathrm{PD}-\mathrm{L} 1 / \mathrm{CD} 8^{\text {high }}$ vs. PD-L1 $/$ CD $8^{\text {low }}$ groups, $\mathrm{p}=0.004$, respectively). In addition, although not statistically significant, the OS of the PD-L1\%CD $8^{\text {high }}$ group also tended to be longer than that of the $\mathrm{PD}-\mathrm{L}^{+} / \mathrm{CD} 8^{\text {high }}$ group $(\mathrm{p}=0.076)$.

\section{DISCUSSION}

CD8+ cytotoxic $\mathrm{T}$ cells are a crucial component of the cellular immune system and play a pivotal role in cell-mediated antitumor immune responses [17, 18]. For example, patients with HNSCC who exhibit a greater number of tumor-infiltrating CD8+ TILs are reported to survive longer [9, 19-21]. Consistent with these studies, we this study demonstrated that a higher $\mathrm{CD} 8^{+} \mathrm{TIL}$ density was significantly associated with long-term survival, indicating that $\mathrm{CD} 8^{+} \mathrm{T}$ cells may play an important role in antitumor immunity in HPSCC patients who received NAC [22]. In addition, the subgroup analysis suggested that further stratification based on PD-L1 expression could be useful for predicting the prognosis of patients with a higher CD8 $8^{+}$TIL density. This suggests that a coassessment of $\mathrm{CD}^{+}$TIL density and PD-L1 expression may be a predictive biomarker for patients with HPSCC receiving NAC.

Several immune-related biomarkers used to predict chemotherapeutic responses have been identified for various types of cancers [23]. For example, a higher $\mathrm{CD}^{+}$TIL density and fewer intraepithelial macrophages in tumors have been found to exhibit a better response to NAC in patients with head and neck cancer [9]. In the present study, the multivariate analysis revealed that $\mathrm{CD} 8^{+}$TIL density was significantly associated with tumor response to NAC. To our knowledge, there have
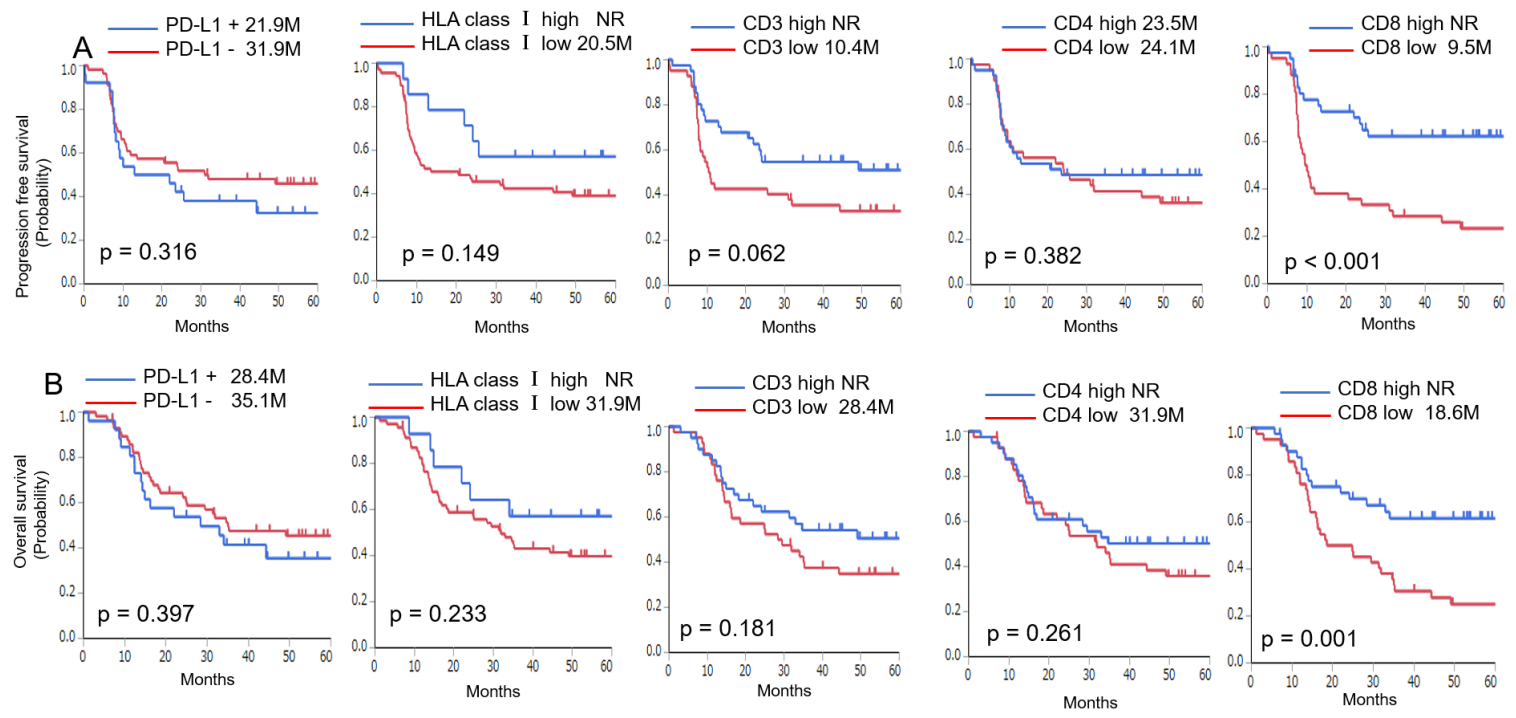

Figure 2: Kaplan-Meier analysis of the progression-free survival (PFS) (A) and overall survival (OS) (B) of patients with advanced hypopharyngeal squamous cell carcinoma exhibiting positive or negative expression of PD-L1, HLA class I, and high or low CD3 ${ }^{+}, \mathrm{CD}^{+}$, and $C D 8^{+}$TIL density. Significant differences were evaluated using a log-rank test. 
Table 4: Univariate and multivariate analyses of clinicopathologic factors associated with PFS and OS

\begin{tabular}{|c|c|c|c|c|c|}
\hline \multirow{4}{*}{ Factor } & \multirow{4}{*}{$\mathbf{N}$} & \multicolumn{2}{|c|}{ PFS } & \multicolumn{2}{|c|}{ OS } \\
\hline & & Univariate & Multivariate & Univariate & Multivariate \\
\hline & & $P$ value ${ }^{a}$ & $P$ value ${ }^{a}$ & $P$ value ${ }^{\mathrm{a}}$ & $P$ value ${ }^{a}$ \\
\hline & & HR (95\% CI) & HR (95\% CI) & HR (95\% CI) & HR (95\% CI) \\
\hline \multicolumn{6}{|l|}{ Age (years) } \\
\hline$\leq 65$ & 42 & 0.521 & & 0.743 & \\
\hline$>65$ & 41 & $1.20(0.68-2.12)$ & & $1.10(0.62-1.95)$ & \\
\hline \multicolumn{6}{|l|}{ Smoking status } \\
\hline Never or Mild & 38 & 0.666 & & 0.345 & \\
\hline Heavy & 45 & $1.13(0.64-1.99)$ & & $1.31(0.74-2.32)$ & \\
\hline \multicolumn{6}{|l|}{ Alcohol status } \\
\hline $\begin{array}{l}\text { Never or } \\
\text { Moderate }\end{array}$ & 43 & 0.461 & & 0.679 & \\
\hline Heavy & 40 & $0.81(0.46-1.42)$ & & $0.89(0.50-1.56)$ & \\
\hline \multicolumn{6}{|l|}{$\begin{array}{l}\text { Performance } \\
\text { status }\end{array}$} \\
\hline 0 & 75 & 0.276 & & 0.188 & 0.298 \\
\hline 1 or 2 & 8 & $0.60(0.28-1.58)$ & & $0.53(0.25-1.41)$ & $0.60(0.26-1.65)$ \\
\hline \multicolumn{6}{|l|}{ Differentiation } \\
\hline Well & 30 & 0.672 & & 0.943 & \\
\hline $\begin{array}{l}\text { Moderately or } \\
\text { poorly }\end{array}$ & 53 & $1.13(0.62-2.01)$ & & $1.02(0.56-1.82)$ & \\
\hline \multicolumn{6}{|l|}{$\mathrm{T}$ classification } \\
\hline $\mathrm{T} 2$ & 15 & 0.464 & 0.581 & 0.437 & 0.602 \\
\hline T3-4 & 68 & $1.29(0.63-2.45)$ & $1.21(0.58-2.34)$ & $1.31(0.64-2.50)$ & $1.21(0.57-2.40)$ \\
\hline \multicolumn{6}{|l|}{$\mathrm{N}$ classification } \\
\hline N0-1 & 23 & 0.060 & 0.102 & 0.029 & 0.048 \\
\hline $\mathrm{N} 2-3$ & 60 & $0.53(0.25-1.02)$ & $0.56(0.26-1.11)$ & $0.47(0.21-0.93)$ & $0.49(0.22-0.99)$ \\
\hline \multicolumn{6}{|l|}{ NAC categories } \\
\hline $\mathrm{PF}$ & 45 & 0.263 & & 0.417 & \\
\hline $\mathrm{TPF}$ & 38 & $0.72(0.41-1.28)$ & & $0.78(0.44-1.41)$ & \\
\hline \multicolumn{6}{|l|}{ HLA class I } \\
\hline High & 14 & 0.127 & & 0.209 & \\
\hline Low & 69 & $0.54(0.20-1.17)$ & & $0.60(0.22-1.30)$ & \\
\hline \multicolumn{6}{|l|}{ PD-L1 } \\
\hline Positive & 26 & 0.326 & 0.070 & 0.405 & 0.073 \\
\hline Negative & 57 & $1.35(0.73-2.43)$ & $1.85(0.95-3.48)$ & $1.30(0.42-1.45)$ & $1.86(0.94-3.57)$ \\
\hline
\end{tabular}




\begin{tabular}{|c|c|c|c|c|c|}
\hline \multirow{4}{*}{ Factor } & \multirow{4}{*}{$\mathbf{N}$} & \multicolumn{2}{|c|}{ PFS } & \multicolumn{2}{|c|}{ OS } \\
\hline & & Univariate & Multivariate & Univariate & Multivariate \\
\hline & & $P$ value ${ }^{a}$ & $P$ value ${ }^{a}$ & $P$ value ${ }^{a}$ & $P$ value ${ }^{a}$ \\
\hline & & HR $(95 \%$ CI $)$ & HR (95\% CI) & HR (95\% CI) & HR (95\% CI) \\
\hline \multicolumn{6}{|l|}{$\mathrm{CD} 3$} \\
\hline High & 41 & 0.063 & 0.437 & 0.181 & 0.596 \\
\hline Low & 42 & $0.59(0.33-1.03)$ & $0.78(0.41-1.46)$ & $0.67(0.38-1.20)$ & $0.84(0.44-1.58)$ \\
\hline \multicolumn{6}{|l|}{ CD4 } \\
\hline High & 41 & 0.385 & 0.517 & 0.260 & 0.301 \\
\hline Low & 42 & $0.78(0.44-1.37)$ & $0.78(0.42-1.44)$ & $0.72(0.40-1.27)$ & $0.72(0.38-1.34)$ \\
\hline \multicolumn{6}{|l|}{ CD8 } \\
\hline High & 41 & $<0.001$ & 0.001 & 0.001 & 0.005 \\
\hline Low & 42 & $0.34(0.18-0.61)$ & $0.33(0.16-0.62)$ & $0.38(0.20-0.70)$ & $0.38(0.19-0.75)$ \\
\hline
\end{tabular}

${ }^{\mathrm{a} C}$ ox proportional hazards model. PFS, progression-free survival; OS, overall survival; CI, confidence interval; NAC, neoadjuvant chemotherapy; PF, cisplatin and 5-fluorouracil; TPF; docetaxel, cisplatin, and 5-fluorouracil.

been no published reports demonstrating that $\mathrm{CD} 8^{+} \mathrm{TIL}$ density may be a useful biomarker for predicting tumor responses to NAC in patients with advanced HPSCC. Because chemotherapy has been reported to change the tumor microenvironment via high antigen exposure and the accumulation of dendritic cells, which stimulate $\mathrm{CD} 8^{+}$ T cells and the type I IFN pathway [24], pre-existing CD8 ${ }^{+}$ TILs may be one of the key components for efficient responses to NAC.
Negative regulatory mechanisms (e.g., increased PD-1 expression) may impact the prognostic importance of $\mathrm{CD}^{+}$TILs. For example, previous reports have demonstrated that patients with high $\mathrm{PD}-1^{+} / \mathrm{CD}^{+}$TILs were associated with a significantly worse prognosis compared to those with low PD-1 $1^{+} / \mathrm{CD} 8^{+}$TILs $[25,26]$. These findings suggest that increased PD-1 expression on $\mathrm{CD}^{+}$TILs may represent an exhausted state of effector cells, thus resulting in a reduced anti-tumor
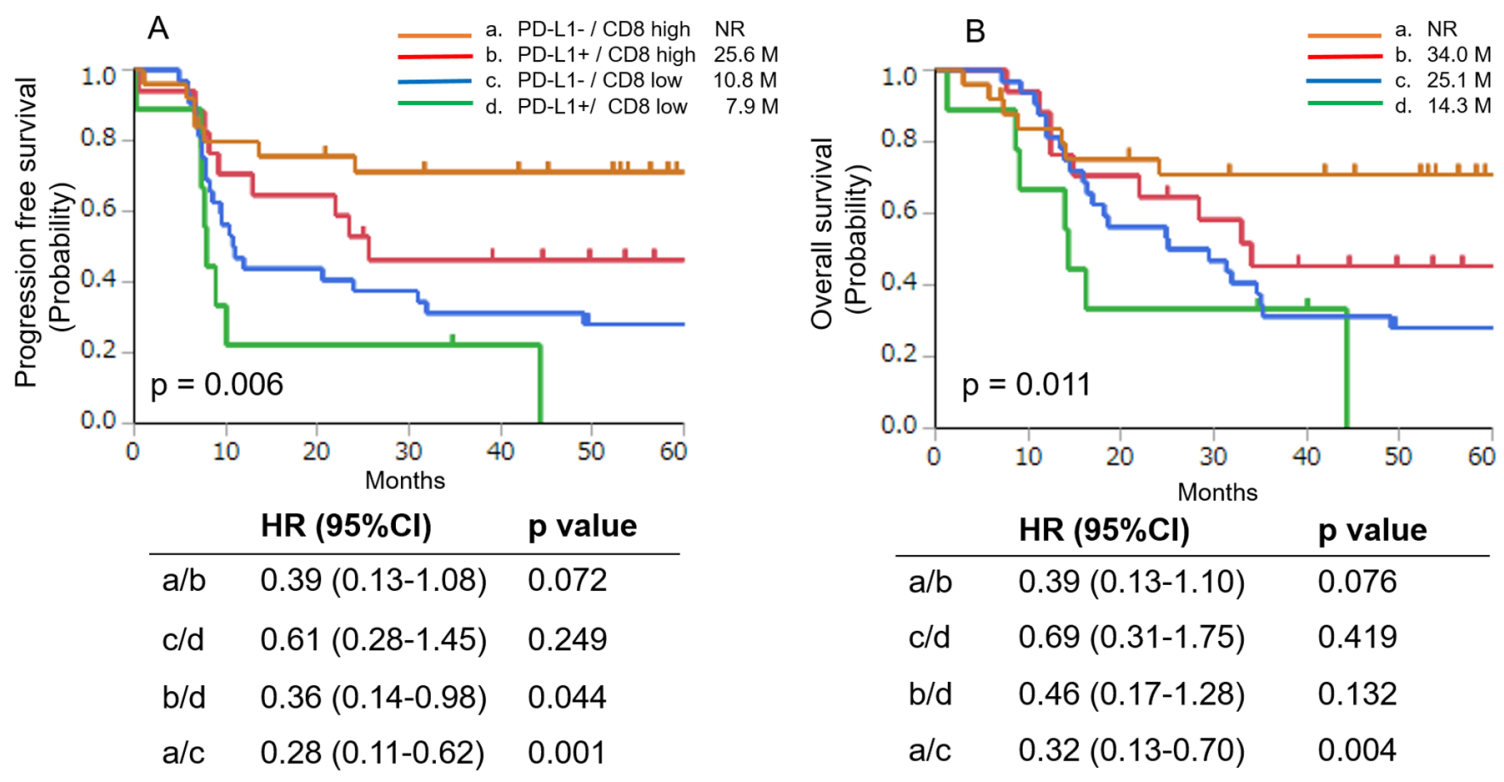

Figure 3: Kaplan-Meier analysis of PFS (A) and OS (B) of patients with positive or negative PD-L1 expression combined with high or low $\mathrm{CD}^{+}$TIL density. Significant differences were evaluated using a log-rank test. 
effect. Therefore, it may be important to investigate the level of PD-1 expression on $\mathrm{CD}^{+}$TILs to distinguish between functional and exhausted $\mathrm{CD} 8^{+} \mathrm{TILs}$. However, unfortunately, we were unable to examine the PD-1 expression in TILs using immunohistochemistry in this study due to the limited number of available tumor tissues for immunohistochemistry. We would like to investigate the significance of the PD- 1 expression on CD8 $8^{+}$TILs in patients with advanced HPSCC in future studies and to report the results in detail in future publications.

Although blockade of the PD-1/PD-L1 pathway using monoclonal antibodies is a novel therapeutic strategy for treating patients with recurrent HNSCC [27], the association between PD-L1 expression and the prognosis of patients with HNSCC has not been well described. Recent studies have demonstrated that higher levels of PD-L1 expression are associated with a poor prognosis in various types of cancers [28-32], whereas other studies have presented controversial results [33-35]. For example, PD-L1 expression was reportedly not associated with patient prognosis in laryngeal and pharyngeal squamous cell carcinoma $[9,36]$. Consistent with these results, the present study did not find a significant correlation between PD-L1 expression and the prognosis of patients with stage III or IV HPSCC who received NAC.

It has been reported that IFN- $\gamma$ produced by tumorspecific TILs could induce PD-L1 expression in tumor cells and/or immune cells as an adaptive immune response. Nevertheless, because CD8 ${ }^{+}$TIL density does not strictly correlate positively with PD-L1 expression, the PD-1/PDL1 axis may function as an immune escape mechanism only in some (but not all) patients; albeit the precise mechanism remains unclear. Therefore, we considered that an evaluation of $\mathrm{CD}^{+}$TIL density could become more meaningful when interpreted in conjunction with PD-L1 expression on tumor cells. The Kaplan-Meier analysis demonstrated that the four subgroups defined by PD-L1 expression and $\mathrm{CD}^{+}$TIL density demonstrated prognostic relevance. Of note, the $\mathrm{PD}-\mathrm{L}^{+} / \mathrm{CD}^{\text {high }}$ group tended to exhibit a worse prognosis than the PD-L1/CD $8^{\text {high }}$ group. In the $\mathrm{PD}-\mathrm{L1}^{+} / \mathrm{CD}^{\text {high }}$ group, PD-L1 expression may be intrinsically expressed or efficiently induced as an adaptive immune escape response, possibly resulting in a worse prognosis. In contrast, in the PD-L1/CD ${ }^{\text {high }}$ group, immune suppressive mechanisms other than the PD-1/ PD-L1 axis [e.g., regulatory $\mathrm{T}$ cells, tumor-associated macrophages, or myeloid-derived suppressor cells (MDSCs)], may be activated for the purpose of immune escape [37, 38]; however, the specific details remain unclear. Based on our finding that the PD-L1\% $/ \mathrm{CD} 8^{\text {high }}$ group tended to have a better prognosis than the $\mathrm{PD}-\mathrm{L}^{+}{ }^{+}$ CD8 ${ }^{\text {high }}$ group, it may be possible that PD-L1 expression could induce more efficient immune suppression than other immune escape mechanisms. Consistent with the current study, previous studies have demonstrated similar results in other tumor types (e.g., lung and gastric cancer) $[16,37]$.

The anti-PD-L1 antibody MPDL3280A has been reported to elicit improved clinical responses in patients with tumors that express high levels of PD-L1 and contain higher numbers of tumor-infiltrating immune cells [39]. Similarly, it has been suggested that patients with tumor cells expressing PD-L1, as well as a high density of $\mathrm{CD}^{+}$ TILs may achieve better outcomes via an anti-PD-1 blocking antibody [38]. Further studies are required to determine the predictive relevance of a co-assessment of PD-L1 expression and CD8 ${ }^{+}$TIL density for selecting patients with HPSCC who are most likely to respond to the PD-1/PD-L1 blocking treatments.

The current retrospective study has several limitations. First, the definitive treatments of the patients following NAC were heterogeneous. Second, the tissue samples obtained using nasal endoscopy were small, and may not reflect the entire tumor. Because the expression of PD-L1 on tumor cells, as well as the TIL density are often heterogeneous even within the same tumors, an accurate evaluation of PD-L1 expression and TIL density in small biopsy samples may occasionally be difficult in this study. Third, the threshold for positive immunohistochemistry results was not formally defined, and reproducibility was not formally assessed. Therefore, future investigations and validations are warranted to harmonize and standardize testing for PD-L1 expression using an immunohistochemical analysis of larger sample sizes.

In conclusion, the current study demonstrated that a higher $\mathrm{CD}^{+}$TIL density was significantly associated with the tumor responses to NAC and long-term survival in patients with advanced HPSCC who received NAC. In addition, our subanalysis suggested that patients who exhibited a higher $\mathrm{CD}^{+}$TIL density without detectable levels of PD-L1 in tumor cells survived longer. We propose that a co-assessment of $\mathrm{CD}^{+} \mathrm{TIL}$ density and PD-L1 expression would have greater predictive potential compared with an evaluation of each factor alone in patients with advanced HPSCC.

\section{MATERIALS AND METHODS}

\section{Patients}

We retrospectively screened consecutive patients diagnosed with stage III or IV HPSCC at Kurume University Hospital between 2000 and 2013. The inclusion criteria were as follows: pathological diagnosis of HPSCC; NAC treatment followed by surgery, definitive concurrent chemoradiotherapy (CCRT) with combined platinumcontaining chemotherapy, or palliation; and the availability of adequate histological specimens containing tumor cells. The present study was conducted in accordance with 
the provisions of the Declaration of Helsinki and was approved by the Institutional Review Boards of Kurume University Hospital.

\section{Immunohistochemical analysis}

We used 4- $\mu$ m-thick sections of formalin-fixed, paraffin-embedded tissues. The sections were mounted on glass slides and then incubated with an anti-rabbit monoclonal antibody against PD-L1 (clone D3; Cell Signaling Technology, Danvers, MA) using a BenchMark ULTRA (Ventana Automated Systems, Inc., Tucson, AZ). Briefly, each slide was heated using the Ventana CC1 retrieval solution for $30 \mathrm{~min}$ and incubated with the PDL1 antibody for $30 \mathrm{~min}$. This automated system used the ultraVIEW DAB detection kit with 3, 3' diaminobenzidine (DAB) as the chromogen (Ventana Automated Systems).

Immunohistochemical analysis of HLA class I (EMR8-5; ab70328; Abcam, Cambridge, England), CD3, CD4, and CD8 expression (Leica Microsystems, Newcastle-upon-Tyne, UK) was performed using a fully automated Bond-III system (Leica Microsystems). Briefly, each slide was treated using onboard heat-induced antigen retrieval with an epitope retrieval solution 2 for $10 \mathrm{~min}$ at $99^{\circ} \mathrm{C}$, incubated with the antibody for $30 \mathrm{~min}$ at room temperature, and then incubated with a secondary antibody for $30 \mathrm{~min}$ at room temperature. This automated system used a Refine polymer detection kit with HRP (horseradish peroxidase)-polymer as the secondary antibody in conjunction with DAB.

All immunohistochemical analyses were evaluated by two observers (A.K. and J.A.) who were unaware of the patients' condition. Disagreements in data interpretation were reviewed jointly, and a single consensus category was established. All patient samples for PD-L1 expression were divided into groups based on the TPS of $<1 \%, 1 \%$ $49 \%$, and $\geq 50 \%$, as detailed previously $[40,41]$. Patients with PD-L1 TPS of $\geq 1 \%$ were considered positive, as described previously [42]. Regarding the expression of HLA class I, we divided the expression levels into three criteria as previously described: 1) positive, expressed on more than $75 \%$ of tumor cells; 2 ) heterogeneous, expressed between $25 \%$ and $74 \%$; and 3 ) negative, expressed on less than $25 \%$ of tumor cells $[43,44]$. Patients with positive HLA class I expression $(\geq 75 \%)$ were defined as the high group. Furthermore, the TIL numbers were counted, and scoring was performed using a four-tier scale. We determined the median values of $\mathrm{CD}^{+}, \mathrm{CD}^{+}$, and $\mathrm{CD} 8^{+}$ TILs to define the cut-off value for TIL density.

\section{Statistical analyses}

Correlations between PD-L1 or HLA class I expression and the patient characteristics were analyzed using Fisher's exact test for categorical variables. We evaluated whether variables, including PD-L1 expression, were associated with the survival of patients with stage III or IV HPSCC who received NAC, followed by definitive treatment or best supportive care. To examine the predictive factors for the NAC response, univariate and multivariate logistic regression analyses were performed. The progression-free survival (PFS) and overall survival (OS) were calculated from the date of initiating NAC to tumor relapse (locoregional recurrence, distant metastasis, or both) or death, respectively. Kaplan-Meier analysis was used to assess patient's survival, and a log-rank test was used to evaluate the significant differences between and among two or four groups, respectively. Multivariate regression analysis was performed using a Cox proportional hazards model. All tests were two-sided, and $p<0.05$ indicates a statistically significant difference. The statistical analyses were conducted using JMP version 11 (SAS Institute Inc., Cary, NC).

\section{Abbreviations}

HPSCC, hypopharyngeal squamous cell carcinoma; PD-L1, programmed cell death-ligand 1; HLA, human leukocyte antigen; TIL, tumor-infiltrating lymphocyte; NAC, neoadjuvant chemotherapy; PD-1, programmed cell death 1; HNC, head and neck cancer; HNSCC, head and neck squamous cell carcinoma; CCRT, concurrent chemoradiotherapy; TPS, tumor proportion score; PFS, progression-free survival; OS, overall survival; $\mathrm{CR}$, complete response; PR, partial responses; $\mathrm{SD}$, stable disease; PD, progressive disease

\section{Author contributions}

All persons undersigned as authors participated in this study and take public responsibility for the content of the manuscript. Takeharu Ono, the first author, designed this study, analyzed the data, and drafted the manuscript. The data was collected by Koichi Azuma, Akihiko Kawahara, Fumihiko Sato, and Buichiro Shin. The experiments were performed by Akihiko Kawahara, Shun-ich Chitose, and Jun Akiba. Statistical analysis was performed by Satoshi Hattori. Tetsuro Sasada and Hirohito Umeno contributed to final approval of the version to be submitted.

\section{CONFLICTS OF INTEREST}

The authors declare that there are no conflicts of interest.

\section{FUNDING}

This research did not receive any specific grant from funding agencies in the public, commercial, or not-forprofit sectors. 


\section{REFERENCES}

1. Cooper JS, Porter K, Mallin K, Hoffman HT, Weber RS, Ang KK, Gay EG, Langer CJ. National Cancer Database report on cancer of the head and neck: 10-year update. Head Neck. 2009; 31:748-58. https://doi.org/10.1002/hed.21022.

2. Carvalho AL, Nishimoto IN, Califano JA, Kowalski LP. Trends in incidence and prognosis for head and neck cancer in the United States: a site-specific analysis of the SEER database. Int J Cancer. 2005; 114:806-16. https://doi. org/10.1002/ijc.20740.

3. Budach W, Bölke E, Kammers K, Gerber PA, Orth K, Gripp S, Matuschek C. Induction chemotherapy followed by concurrent radio-chemotherapy versus concurrent radio-chemotherapy alone as treatment of locally advanced squamous cell carcinoma of the head and neck (HNSCC): a meta-analysis of randomized trials. Radiother Oncol. 2016; 118:238-43. https://doi.org/10.1016/j.radonc.2015.10.014.

4. Lefebvre JL, Andry G, Chevalier D, Luboinski B, Collette L, Traissac L, de Raucourt D, Langendijk JA; EORTC Head and Neck Cancer Group. Laryngeal preservation with induction chemotherapy for hypopharyngeal squamous cell carcinoma: 10-year results of EORTC trial 24891. Ann Oncol. 2012; 23:2708-14. https://doi.org/10.1093/annonc/ mds065.

5. Henriques De Figueiredo B, Fortpied C, Menis J, Lefebvre JL, Barzan L, de Raucourt D, Geoffrois L, Giurgea L, Hupperets P, Leemans CR, Licitra L, Rolland F, Tesselaar $\mathrm{M}$, et al. Long-term update of the 24954 EORTC phase III trial on larynx preservation. Eur J Cancer. 2016; 65:109-12. https://doi.org/10.1016/j.ejca.2016.06.024.

6. Cognetti F, Pinnarö P, Ruggeri EM, Carlini P, Perrino A, Impiombato FA, Calabresi F, Chilelli MG, Giannarelli D. Prognostic factors for chemotherapy response and survival using combination chemotherapy as initial treatment of advanced head and neck squamous cell cancer. J Clin Oncol. 1989; 7:829-37.

7. Montero EH, Trufero JM, Romeo JA, Terré FC. Comorbidity and prognosis in advanced hypopharyngeallaryngeal cancer under combined therapy. Tumori. 2008; 94:24-9.

8. Karpathiou G, Giroult JB, Forest F, Fournel P, Monaya A, Froudarakis M, Dumollard JM, Prades JM, Gavid M, Peoc'h M. Clinical and histologic predictive factors of response to induction chemotherapy in head and neck squamous cell carcinoma. Am J Clin Pathol. 2016; 146:54653. https://doi.org/10.1093/ajcp/aqw145.

9. Karpathiou G, Casteillo F, Giroult JB, Forest F, Fournel P, Monaya A, Froudarakis M, Dumollard JM, Prades JM, Peoc'h M. Prognostic impact of immune microenvironment in laryngeal and pharyngeal squamous cell carcinoma: immune cell subtypes, immuno-suppressive pathways and clinicopathologic characteristics. Oncotarget. 2016; 8:19310-22. https://doi.org/10.18632/oncotarget.14242.
10. Pardoll DM. The blockade of immune checkpoints in cancer immunotherapy. Nat Rev Cancer. 2012; 12:252-64. https:// doi.org/10.1038/nrc3239.

11. Rizvi NA, Mazières J, Planchard D, Stinchcombe TE, Dy GK, Antonia SJ, Horn L, Lena H, Minenza E, Mennecier B, Otterson GA, Campos LT, Gandara DR, et al. Activity and safety of nivolumab, an anti-PD-1 immune checkpoint inhibitor, for patients with advanced, refractory squamous non-small-cell lung cancer (CheckMate 063): a phase 2, single-arm trial. Lancet Oncol. 2015; 16:257-65. https:// doi.org/10.1016/S1470-2045(15)70054-9.

12. Weber JS, D'Angelo SP, Minor D, Hodi FS, Gutzmer R, Neyns B, Hoeller C, Khushalani NI, Miller WH Jr, Lao CD, Linette GP, Thomas L, Lorigan P, et al. Nivolumab versus chemotherapy in patients with advanced melanoma who progressed after anti-CTLA-4 treatment (CheckMate 037): a randomised, controlled, open-label, phase 3 trial. Lancet Oncol. 2015; 16:375-84. https://doi.org/10.1016/ S1470-2045(15)70076-8.

13. Hodi FS, O'Day SJ, McDermott DF, Weber RW, Sosman JA, Haanen JB, Gonzalez R, Robert C, Schadendorf D, Hassel JC, Akerley W, van den Eertwegh AJ, Lutzky J, et al. Improved survival with ipilimumab in patients with metastatic melanoma. N Engl J Med. 2010; 363:711-23. https://doi.org/10.1056/NEJMoa1003466.

14. Sobin LH, Gospodarowicz MK, Wittekind CH. TNM Classification of Malignant Tumours, 7th. New York: John Wiley \& Sons; 2009. p 30-38.

15. Taube JM, Anders RA, Young GD, Xu H, Sharma R, McMiller TL, Chen S, Klein AP, Pardoll DM, Topalian SL, Chen L. Colocalization of inflammatory response with B7-h1 expression in human melanocytic lesions supports an adaptive resistance mechanism of immune escape. Sci Transl Med. 2012; 4:127ra37. https://doi.org/10.1126/ scitranslmed.3003689.

16. Tokito T, Azuma K, Kawahara A, Ishii H, Yamada K, Matsuo N, Kinoshita T, Mizukami N, Ono H, Kage M, Hoshino T. Predictive relevance of PD-L1 expression combined with CD8+ TIL density in stage III nonsmall cell lung cancer patients receiving concurrent chemoradiotherapy. Eur J Cancer. 2016; 55:7-14. https:// doi.org/10.1016/j.ejca.2015.11.020.

17. Barry M, Bleackley RC. Cytotoxic T lymphocytes: all roads lead to death. Nat Rev Immunol. 2002; 2:401-9. https://doi. org/10.1038/nri819.

18. Fridman WH, Pages F, Sautes-Fridman C, Garon J. The immune contexture in human tumours: impact on clinical outcome. Nat Rev Cancer. 2012; 12:298-306. https://doi. org/10.1038/nrc3245.

19. Kim HR, Ha SJ, Hong MH, Heo SJ, Koh YW, Choi EC, Kim EK, Pyo KH, Jung I, Seo D, Choi J, Cho BC, Yoon SO. PD-L1 expression on immune cells, but not on tumor cells, is a favorable prognostic factor for head and neck cancer 
patients. Sci Rep. 2016; 6:36956. https://doi.org/10.1038/ srep36956.

20. Balermpas P, Rödel F, Rödel C, Krause M, Linge A, Lohaus F, Baumann M, Tinhofer I, Budach V, Gkika E, Stuschke M, Avlar M, Grosu AL, et al. CD8+ tumour-infiltrating lymphocytes in relation to HPV status and clinical outcome in patients with head and neck cancer after postoperative chemoradiotherapy: a multicentre study of the German cancer consortium radiation oncology group (DKTK-ROG). Int J Cancer. 2016; 138:171-81. https://doi.org/10.1002/ ijc. 29683 .

21. Balermpas P, Michel Y, Wagenblast J, Seitz O, Weiss C, Rödel F, Rödel C, Fokas E. Tumour-infiltrating lymphocytes predict response to definitive chemoradiotherapy in head and neck cancer. Br J Cancer. 2014; 110:501-9. https://doi. org/10.1038/bjc.2013.640.

22. Kershaw MH, Teng MW, Smyth MJ, Dancy PK. Supernatural T cells: genetic modification of T cells for cancer therapy. Nat Rev Immunol. 2005; 5:928-40. https:// doi.org/10.1038/nri1729.

23. Galluzzi L, Senovilla L, Zitvogel L, Kroemer G. The secret ally: immunostimulation by anticancer drugs. Nat Rev Drug Discov. 2012; 11:215-33. https://doi.org/10.1038/nrd3626.

24. Kang TH, Mao CP, Lee SY, Chen A, Lee JH, Kim TW, Alvarez RD, Roden RB, Pardoll D, Hung CF, Wu TC. Chemotherapy acts as an adjuvant to convert the tumor microenvironment into a highly permissive state for vaccination-induced antitumor immunity. Cancer Res. 2013; 73:2493-504. https://doi.org/10.1158/0008-5472.

25. Lim YJ, Koh J, Kim K, Chie EK, Kim B, Lee KB, Jang JY, Kim SW, Oh DY, Bang YJ, Ha SW. High ratio of programmed cell death protein $1(\mathrm{PD}-1)(+) / \mathrm{CD} 8(+)$ tumorinfiltrating lymphocytes identifies a poor prognostic subset of extrahepatic bile duct cancer undergoing surgery plus adjuvant chemoradiotherapy. Radiother Oncol. 2015; 117:165-70. https://doi.org/10.1016/j.radonc.2015.07.003.

26. Hsu MC, Hsiao JR, Chang KC, Wu YH, Su IJ, Jin YT, Chang Y. Increase of programmed death-1-expressing intratumoral CD8 $\mathrm{T}$ cells predicts a poor prognosis fornasopharyngealcarcinoma. Mod Pathol. 2010; 23:1393403. https://doi.org/10.1038/modpathol.2010.130.

27. Ferris RL, Blumenschein G Jr, Fayette J, Guigay J, Colevas AD, Licitra L, Harrington K, Kasper S, Vokes EE, Even C, Worden F, Saba NF, Iglesias Docampo LC, et al. Nivolumab for recurrent squamous-cell carcinoma of the head and neck. N Engl J Med. 2016; 375:1856-67. https://doi.org/10.1056/ NEJMoa1602252.

28. Mu CY, Huang JA, Chen Y, Chen C, Zhang XG. High expression of PD-L1 in lung cancer may contribute to poor prognosis and tumor cells immune escape through suppressing tumor infiltrating dendritic cells maturation. Med Oncol. 2011; 28:682-8. https://doi.org/10.1007/ s12032-010-9515-2.

29. Chen YB, Mu CY, Huang JA. Clinical significance of programmed death-1 ligand-1 expression in patients with non-small cell lung cancer: a 5-yearfollow-up study. Tumori. 2012; 98:751-5. https://doi. org/10.1700/1217.13499.

30. Shin SJ, Jeon YK, Kim PJ, Cho YM, Koh J, Chung DH, Go H. Clinicopathologic analysis of PD-L1 and PD-L2 expression in renal cell carcinoma: association with oncogenic proteins status. Ann Surg Oncol. 2016; 23 :694702. https://doi.org/10.1245/s10434-015-4903-7.

31. Schalper KA, Velcheti V, Carvajal D, Wimberly $H$, Brown J, Pusztai L, Rimm DL. In situ tumor PD-L1 mRNA expression is associated with increased tils and better outcome in breast carcinomas. Clin Cancer Res. 2014; 20:2773-82. https://doi.org/10.1158/1078-0432. CCR-13-2702.

32. Lin YM, Sung WW, Hsieh MJ, Tsai SC, Lai HW, Yang SM, Shen KH, Chen MK, Lee H, Yeh KT, Chen CJ. High PD-L1 expression correlates with metastasis and poor prognosis in oral squamous cell carcinoma. PLoS One. 2015; 10:e0142656. https://doi.org/10.1371/journal. pone. 0142656 .

33. Motoshima T, Komohara Y, Ma C, Dewi AK, Noguchi H, Yamada S, Nakayama T, Kitada S, Kawano Y, Takahashi W, Sugimoto M, Takeya M, Fujimoto N, et al. PD-L1 expression in papillary renal cell carcinoma. BMC Urol. 2017; 17:8. https://doi.org/10.1186/s12894-016-0195-X.

34. Park IH, Kong SY, Ro JY, Kwon Y, Kang JH, Mo HJ, Jung SY, Lee S, Lee KS, Kang HS, Lee E, Joo J, Ro J. Prognostic implications of tumor-infiltrating lymphocytes in association with programmed death ligand 1 expression in early-stage breast cancer. Clin Breast Cancer. 2016; 16:51-8. https://doi.org/10.1016/j.clbc.2015.07.006.

35. Vassilakopoulou M, Avgeris M, Velcheti V, Kotoula V, Rampias T, Chatzopoulos K, Perisanidis C, Kontos CK, Giotakis AI, Scorilas A, Rimm D, Sasaki C, Fountzilas $\mathrm{G}$, et al. Evaluation of PD-L1 expression and associated tumor-infiltrating lymphocytes in laryngeal squamous cell carcinoma. Clin Cancer Res. 2016; 22:704-13. https://doi. org/10.1158/1078-0432.CCR-15-1543.

36. Chang AM, Chiosea SI, Altman A, Pagdanganan HA, Ma C. Programmed death-ligand 1 expression, microsatellite instability, epstein-barr virus, and human papillomavirus in nasopharyngeal carcinomas of patients from the Philippines. Head Neck Pathol. 2017; 11:203-11. https:// doi.org/10.1007/s12105-016-0765-y.

37. Koh J, Ock CY, Kim JW, Nam SK, Kwak Y, Yun S, Ahn SH, Park DJ, Kim HH, Kim WH, Lee HS. Clinicopathologic implications of immune classification by PD-L1 expression and CD8-positive tumor-infiltrating lymphocytes in stage II and III gastric cancer patients. Oncotarget. 2017; 8:2635667. https://doi.org/10.18632/oncotarget.15465.

38. Teng MW, Ngiow SF, Ribas A, Smyth MJ. Classifying cancers based on T-cell infiltration and PD-L1. Cancer Res. 2015; 75:2139-45. https://doi.org/10.1158/0008-5472. CAN-15-0255. 
39. Herbst RS, Soria JC, Kowanetz M, Fine GD, Hamid O, Gordon MS, Sosman JA, McDermott DF, Powderly JD, Gettinger SN, Kohrt HE, Horn L, Lawrence DP, et al. Predictive correlates of response to the anti-PD-L1 antibody MPDL3280A in cancer patients. Nature. 2014; 515:563-7. https://doi.org/10.1038/nature14011.

40. Roach C, Zhang N, Corigliano E, Jansson M, Toland G, Ponto G, Dolled-Filhart M, Emancipator K, Stanforth D, Kulangara K. Development of a companion diagnostic PD-L1 immunohistochemistry assay for pembrolizumab therapy in non-small-cell lung cancer. Appl Immunohistochem Mol Morphol. 2016; 24:392-7. https:// doi.org/10.1097/PAI.029426R1029426R10408.

41. Langer CJ, Gadgeel SM, Borghaei H, Papadimitrakopoulou VA, Patnaik A, Powell SF, Gentzler RD, Martins RG, Stevenson JP, Jalal SI, Panwalkar A, Yang JC, Gubens $\mathrm{M}$, et al. Carboplatin and pemetrexed with or without pembrolizumab for advanced, non-squamous non-small-cell lung cancer: a randomised, phase 2 cohort of the open-label
KEYNOTE-021 study. Lancet Oncol. 2016; 17:1497-508. https://doi.org/10.1016/S1470-2045(16)30498-3.

42. Yu H, Batenchuk C, Badzio A, Boyle TA, Czapiewski P, Chan DC, Lu X, Gao D, Ellison K, Kowalewski AA, Rivard CJ, Dziadziuszko R, Zhou C, et al. PD-L1 expression by two complementary diagnostic assays and mRNA in situ hybridization in small cell lung cancer. J Thorac Oncol. 2017; 12:110-20. https://doi.org/10.1016/j.jtho.2016.09.002.

43. Lee HJ, Kim JY, Park IA, Song IH, Yu JH, Ahn JH, Gong G. Prognostic prognostic significance of tumor-infiltrating lymphocytes and the tertiary lymphoid structures in HER2positive breast cancer treated with adjuvant trastuzumab. Am J Clin Pathol. 2015; 144:278-88. https://doi. org/10.1309/AJCPIXUYDVZ0RZ3G.

44. Garrido F, Perea F, Bernal M, Sánchez-Palencia A, Aptsiauri N, Ruiz-Cabello F. The escape of cancer from $\mathrm{T}$ cell-mediated immune surveillance: HLA class I loss and tumor tissue architecture. Vaccines (Basel). 2017; 5:E7. https://doi.org/10.3390/vaccines5010007. 